\title{
Using Glass’'Analysis Method to Improve the Students’ Speaking Skill
}

\author{
Kasmin Irwan \\ English Education Department Faculty of Teacher Training and Education \\ Muhammadiyah University of Makassar \\ E-mail: kasminbluerock@yahoo.co.id
}

\begin{abstract}
This research aimed at explaining the use of Glass' Analysis Method in improving the students' pronunciation in speaking at the seventh grade students of SMP Negeri 1 Salomekko Kab. Bone. The researcher used pre-experimental design with one group pretest and posttest design. The population was the seventh grade students of SMP Negeri 1 Salomekko Kab. Bone., in academic year 2017/2018, which consisted of six classes. The sample was taken by purposive sampling technique and the total number of sample was 26 students. It conducted in six meetings. It was administered speaking test as instrument. The findings of the data indicated that there was significant difference between students' post-test and pre-test. The mean score in post-test (8.10) was greater than the mean score in pre-test (5.42). From t-test, the researcher found that the value of $t$-test (8.61) was greater than t-table (2.060) at the level of significance 0.05 with degree of freedom $(d f)=25$. Thus, the alternative hypothesis (H1) was accepted and the null hypothesis (HO) was rejected. It means that there was a significant difference in the students' pronunciation in speaking before and after being taught by using Glass' Analysis Method
\end{abstract}

Key words: Research experiment, Speaking Skills, Glass' Analysis Method, Teaching Pronunciation, EFL/ESL

\section{INTRODUCTION}

There are four skills that we have already known in English, namely writing, speaking, reading and listening. Later, the skills should be taught better to master and get complete thought about English itself because each skill has general or specific function in communicating. But we cannot deny that speaking is the most important one for asking information and conversely for delivering information, speaking is the direct system of communication.

Speaking is like the first assessment for each learner who is studying English and each learner has to speak. This statement means an obligation, duty, task, fact, implementation, process, and it can be learning, although we still find some students are speaking little or even passive in the classroom, and it can be caused of many things include the students, the class situation, environment, teaching method, technique, approach or even from the teachers who cannot deliver their material successfully.

In this last century, many linguists and educators give more attention in action research to teach English as a foreign language. According to Hopkins in (Gabel, 1995) that Action Research (AR) represents a growing field of educational research whose chief identifying characteristic is the recognition of the pragmatic requirements of educational 
practitioners for organized reflective inquiry into classroom instruction. $A R$ is a process designed to empower all participants in the educational process (students, instructors and other parties) with the means to improve the practices conducted within the educational experience. In also addition (Kemmis, McTaggart, \& Nixon, 2014) stated that Classroom action research typically involves the use of qualitative, interpretive modes of enquiry and data collection by teachers (often with help from academic partners) with a view to teachers making judgments about how to improve their own practices.

The researcher has found similar case in SMP Negeri 3 Sungguminasa, VII H class where the students cannot say something perfectly in English. They do not know what they must say and how to say, they look very confuse to express the ideas on their mind even not active enough on their speaking class, and it can be seen as the last score of the students that almost do not achieve minimal criteria, 64. According to the teacher's experiences that the problem relates directly to the teaching method and how the teacher delivers material. There is no specific method to teach English, we are not controlling the class but we are controlled by the class and situation. Speaking is the most important lesson that the students should be mastered, but in fact speaking becomes the most difficult lesson to understand by the students, so that the speaking always becomes passive class in every meeting.

There are many techniques can be adopted by the teacher in teaching this skill, and one of them is Glass' analysis method, and it is also recommended by the researcher after considering the case above. Glass' analysis method is from the replaces oral English learning classroom with a conversation English experience.

Glass analysis method is a form of analytic phonics that is compatible with his research on how successful decoders acquired word decoding strategies. Glass research is supported by the conclusions being reached by many others as to how this ultimately is achieved. Glass Analysis resembles an old fashioned approach that taught high utility letter sound combinations. It teaches students to segment sound combinations and distinctive combination feature words.

In glass' analysis, the act of decoding is temporarily decontextualized from comprehension in order to maximize the student focused attention on target words and word elements. Student are trained in conventional and personal word analysis strategies that center on studying and learning how certain letters excite one another meaning that because the reader has seen and sounded a particular letter cluster in whole words many and many 
words, when the letters appear as a cluster in unfamiliar words, the reader automatically identifies them and test-pronounces them as they are pronounced in the known words.

Based on the explanation above, the researcher formulates a research questions as follow “is the use of Glass' Analysis Method effective in improving the students' pronunciation in speaking at the seventh grade students of SMP Negeri 1 Salomekko Kab. Bone"?

\section{METHOD}

The design of this research was pre-experimental design which one group pre-test and post-test design. The group was given pretest, treatment by using Glass' Analysis Method, and post-test. The purpose of the research was to find out the effect of using Glass' Analysis Method in speaking. This design was presented as follows:

Where; $\mathrm{E}=$ Experimental Class

\begin{tabular}{|c|c|c|c|}
\hline Class & Pre-test & Treatment & Post-test \\
\hline $\mathrm{E}$ & $\mathrm{O}_{1}$ & $\mathrm{X}$ & $\mathrm{O}_{2}$ \\
\hline
\end{tabular}

$$
\begin{aligned}
& \mathrm{O}_{1}=\text { Pre-test } \\
& \mathrm{O}_{2}=\text { Post-test } \\
& \mathrm{X}=\text { Treatment by using Glass' Analysis Method (Gay, 1981) }
\end{aligned}
$$

This research consisted of two variables, dependent variable and independent variable. Independent variable was the Glass' Analysis Method which gives effect on teaching and learning speaking. Dependent variable was improvement of the students' speaking skill since it took effect from Glass' Analysis Method focused on pronunciation.

The indicator in this research was the students' improvement in speaking skill the end of every meeting after learning process using Glass' Analysis Method that focus on pronunciation. Population of the research was the seventh grade students of SMP Negeri 1 Salomekko Bone regency on that consisted of 6 classes students. Each class had 25-31 students. Class 7A consisted of 31 students, 7 B consisted of 30 students, 7 C consisted of 26 students, 7D consisted 26 students, 7 E consisted of 31 students, 7 F consisted of 30 students, so total the population is 174 students.

The researcher took sample using purposive sampling technique where the researcher took one class as sample, namely class $7 \mathrm{C}$ because the students of the class had lower percentage than other class.

The instruments of the research used in collecting the data were oral test and recorder. The dialogue was given to measure the students' speaking ability. The dialogue test consist of 
some word that have letter cluster like in the recommended for use Glass' Analysis method. The data of glass analysis method effectiveness in learning to speak was collected through pretest and posttest. The pretest was administered to the students at the first meeting or before the time of treatment to the class while the posttest was given after the treatment.

Before doing the treatment, the students were given pre-test to know the students' prior skill in speaking especially pronunciation

After giving the pre-test, the students were treated by using glass analysis method.In this case, the students were taught to pronounce words which had similar letter cluster. The treatment was conducted six times. It spends $2 \times 45$ minutes or two hours according to the English program schedule.The researcher conducted six meetings. The procedures of treatment from day second meeting until seventh meeting were same.

After the treatment, the post-test was conducted to find out the students' achievement in learning speaking. It was used to check the result of treatments; it was also be useful to know whether glass analysis method is effective to be used in learning speaking and can make students decode letters order correctly in speaking. The test was the same with pre test

Audio recorder was used to collect the data when the students were speaking. It was used twice, in pre-test and post-test. After recording the students' speaking test, then it was analyzed by comparing with the given dialogue whether they had pronounced the words correctly or not.

The collect data analyzed through these steps are as follow:

\begin{tabular}{|c|l|c|}
\hline No & \multicolumn{1}{|c|}{ Criteria } & Score \\
\hline 1 & $\begin{array}{l}\text { Occasional non-native pronunciation errors, but the speaker is } \\
\text { always intelligible }\end{array}$ & 4 \\
\hline 2 & $\begin{array}{l}\text { Some consistent phonemic errors and foreign stress and } \\
\text { intonation patterns, but the speaker is intelligible. }\end{array}$ & 3 \\
\hline 3 & $\begin{array}{l}\text { Frequent phonemic errors and foreign stress and intonation } \\
\text { patterns that cause the speaker to be occasionally unintelligible }\end{array}$ & 2 \\
\hline 4 & $\begin{array}{l}\text { Frequent phonemic errors and foreign stress and intonation } \\
\text { patterns that cause the speaker to be unintelligible }\end{array}$ & 1 \\
\hline
\end{tabular}

(B. H. Douglas, 2003) 
Classifying the students' score use the following scale:

\begin{tabular}{|l|l|l|}
\hline NO & \multicolumn{1}{|c|}{ Classification } & \multicolumn{1}{c|}{ Score } \\
\hline 1 & $9.6-10$ & Excellent \\
2. & $8.6-9.5$ & Very Good \\
3. & $7.6-8.5$ & Good \\
4. & $6.6-7.5$ & Fairly Good \\
5. & $5.6-6.5$ & Fair \\
6 & $4.6-5.5$ & Poor \\
7. & $0-4.5$ & Very Poor \\
\hline
\end{tabular}

Dekdikbud in (Ruslan, 2010)

\section{RESULT AND DISCUSSION}

The data were collected by administrating the test, the tests were done twice namely pre-test and post-test, the pre-test was given before the treatment and the post-test was given after treatment.

Table 3.1

The rate percentage of the students' score before the treatments were given

\begin{tabular}{|ccccc|}
\hline No & Classification & Score & Frequency & Percentage \\
\hline 1. & Excellent & $9.6-10$ & 1 & 3.85 \\
\hline 2. & Very Good & $8.6-9.5$ & 3 & 11.54 \\
\hline 3. & Good & $7.6-8.5$ & 1 & 3.85 \\
\hline 4. & Fairly Good & $6.6-7.5$ & 1 & 3.85 \\
\hline 5. & Fair & $5.6-6.5$ & 4 & 15.38 \\
\hline 6. & Poor & $4.6-5.5$ & 4 & 15.38 \\
\hline 7 & Very Poor & $0-4.5$ & 12 & 46.15 \\
\hline & Total & & 26 & $100 \%$ \\
\hline
\end{tabular}

Table 3.1 shows that before treatments were given, There were one of the student (3.85\%) acquired Excellent score, three student (11.54\%) acquired Very Good score, 1 students $(3.85 \%)$ acquired Good score, 1 students (3.85\%) acquired Fairly Good score, four student (15.38\%) acquired Fair score, 4 students (15.38\%) acquired Poor score, and 12 students $(46.15 \%)$ acquired Very Poor score. The mean score 5.42 indicates that before the treatments were given, the level of the students' ability in pronunciation ability was categorized "Very Poor" classification. 
Table 3.2

The rate percentage of the students' score after the treatments were given

\begin{tabular}{|ccccc|}
\hline No & Classification & Score & Frequency & Percentage \\
\hline 1. & Excellent & $9.6-10$ & 8 & 30.77 \\
\hline 2. & Very Good & $8.6-9.5$ & 4 & 15.38 \\
\hline 3. & Good & $7.6-8.5$ & 4 & 15.38 \\
\hline 4. & Fairly Good & $6.6-7.5$ & 3 & 11.54 \\
\hline 5. & Fair & $5.6-6.5$ & 3 & 11.54 \\
\hline 6. & Poor & $4.6-5.5$ & 3 & 11.54 \\
\hline 7 & Very Poor & $0-4.5$ & 1 & 3.85 \\
\hline & Total & & 26 & $100 \%$ \\
\hline
\end{tabular}

Table 3.2 shows that after treatments were given, There were 8 of the student (30.77\%) acquired Excellent score, 4 student (15.38\%) acquired Very Good score, 4 students (15.38\%) acquired Good score, 3 students (11.54\%) acquired Fairly Good score, 3 student (11.54\%) acquired Fair score, 3 students (11.54\%) acquired Poor score, and 1 students (3.85\%) acquired Very Poor score.. The mean score of the students was 8.10. It indicates that there was a significant different between the results of the students' pre-test and post-test.

Table 3.3

Mean score of the students' pre-test and post-test

\begin{tabular}{|c|c|c|}
\hline Variable & Mean Score & Standard Deviation \\
\hline Pre-test (X1) & 5.42 & 2.27 \\
\hline Post-test (X2) & 8.10 & 1.86 \\
\hline
\end{tabular}

The table 4.3 above shows that the mean score of the students pre-test was 5.42 while the mean score the students post-test was 8.10 furthermore, the standard deviation of the students pre-test was 2.27 while the standard deviation of the students post-test was 1.86 . It revaluated that the mean score and standard deviation of pre-test and post-test obtained by the students are different.

In order to know whether or not the mean score was different significantly from the pre-test and post-test at the level of significance 0.5 with the degree of freedom $(\mathrm{df})=\mathrm{N}-1$, where $\mathrm{N}=$ number of subject (26), the t-test statistical analysis for non-independent sample was applied. The following table shows the result of the t-test calculation:

Table 3.4

The t-test of the students' achievement

\begin{tabular}{|c|c|c} 
Variable & t-test value & t-table value \\
$\mathrm{X} 2-\mathrm{X} 1$ & 8.61 & 2.060 \\
\hline
\end{tabular}


Table 3.4 indicates the value of the t-test was higher than the value of the t-table. It indicates that there was a significant different between the results of the students' pre-test and post-test.

From the analysis above, the researcher concludes that there was a significant difference between the result of the students' pre-test and post-test in improving the students' pronunciation in speaking by using glass' analysis method after giving treatments.

The description of the data collected through Glass' Analysis Method described in the previous section showed that the students' pronunciation in speaking has improved. It was supported by the frequency and the rate percentage of the result of the student's score of pretest and posttest. The student's score after presenting in teaching speaking through Glass' Analysis Method was better than before then the treatment was given to the students

The students were also very interested in learning speaking by Glass' Analysis Method as shown on the table. Based on the result of t-test, the researcher found that there was a significant difference between the results of pre-test and post-test. It means that there was a significant difference result of the pre-test before and after teaching and learning process by using Glass' Analysis Method. This was because learned by using an interesting method that could enlarge their new experience and knowledge.

Relating to the data collected through the pre-test and post-test, it was shown the student's speaking skill of SMP Negeri 1 Salomekko, Kab. Bone was good. The mean score in pre-test was (5.42), while the mean score in posttest was (8.10). It means that, the mean score in pre-test was lower than mean score in post-test.

It was supported by the frequency and the rate percentage of the result of the students' score of pre-test and post-test. The students' score after presenting in teaching speaking through Glass' Analysis Method was better than before the treatment was given to the students. The result of the test showed there was significance different between t-table and t-test $(2.060<8,61)$, its mean that t-table was lower than t-test.

From the result above, Glass' Analysis Method as Glass and Burton in (Manzo \& Manzo, 1995) stated in the previous research findings that it is resembles an old fashioned approach that taught high utility letter sound combinations. It teaches students to segment sound combinations and distinctive combination feature words. So, it could be used in pronunciation in speaking activity in the classroom and it could be improved students speaking. (Penney, 2002) in her journal pointed out, Glass' Analysis method have three rationale to using that, one of the rationale is the ability to segment a syllable into onset and 
rime develops before and may be prerequisite to phonemic awareness. So it is good method to improve students' pronunciation in speaking before at the advance level, because like said by Treiman and Zukowski (1991) in (Penney, 2002) that preschool, kindergarten, and firstgrade children could all identify words that contained identical syllable.

Furthermore, in glass analysis that student are trained in conventional and personal word analysis strategies that center on studying and learning how certain letters excite one another meaning that because the reader has seen and sounded a particular letter cluster in whole words many and many words, when the letters appear as a cluster in unfamiliar words, the reader automatically identifies them and test-pronounces them as they are pronounced in the known words. It's mean that glass Analysis method have correlation in pronunciation where the students seem their mistake in speaking because as the explain in steps of Glass' Analysis method that they showed a letter clusters and whole words that contained same letter clusters.

Afterwards, (Glass \& Glass, 1970) stated Glass Analysis method can be used with individuals or groups (small or large), Does not depend upon anyone's (pupil or teacher) knowledge of rules or principles, Is based upon sound, accepted principles of learning and years of successful application in the nation's schools. The conclude of advantage of the method that it can apply in junior high school and improved their speaking specially in pronunciation.

Finally, the writer concludes that the use Glass' Analysis Method improves students' pronunciation in speaking.

\section{CONCLUSION}

Based on the finding and discussion in the previous chapter in this study, the researcher concludes that Glass' Analysis Method effective in improving the students' pronunciation in speaking. It was proved by pre-test (5.42) compared to the mean score of the post-test was (8.10). In the other hand the result of the statistical analysis at the level of significance 0.5 with the degree of freedom $(\mathrm{df})=\mathrm{N}-1$, where $\mathrm{N}=$ number of subject $(26)$. Indicated that t-test value was 8.61 while table was 2.060 where $8.61>2.60$. The researchers assumes the using of Glass' Analysis Method could improve the students' pronunciation in speaking. They were enthusiastic and interested enough in their learning. Finally, Based on the result, hypothesis test showed that $\mathrm{H}_{0}$ was rejected and $\mathrm{H}_{1}$ was accepted. 


\section{REFERENCES}

Douglas, B. H. (2003). Language Assessment Principles and Classroom Practice. San Fransisco: San Fransisco State University.

Gabel, D. (1995). An Introduction to Action Research. Retrieved July, 27, 2006.

Gay, L. R. (1981). Educational Research: Competencies for Analysis and Application. USA: Merril Publishing Company.

Glass, .Gerald, \& Glass, E. W. (1970). Discover Glass Analysis. Retrieved from http://www.glassanalysis.com/index.html

Kemmis, S., McTaggart, R., \& Nixon, R. (2014). The Action Research Planner: Doing Critical Participatory Action Research. Singapore Heidelberg New York Dordrecht London: Springer.

Manzo, A. V., \& Manzo, U. C. (1995). Teaching Children to be Literate: A Reflective Approach. LiteracyLeaders.

Penney, C. G. (2002). Teaching Decoding Skills to Poor Readers in High School. Journal of Literacy Research, 34(1), 99-118. https://doi.org/10.1207/s15548430j1r3401_4

Ruslan, S. S. (2010). Improving Reading Comprehension of the Second Year Studentsof Smp Negeri 8 Makassar through Reciprocal Teaching Technique. State University Of Makassar, Makassar. 